\title{
Olfactory Nerve Schwannoma: A Case Report and Review of the Literature
}

\author{
Mahmoud M. Taha, MD, PhD ${ }^{1}$ Amr AlBakry, MD ${ }^{1}$ Magdy ElSheikh, MD ${ }^{1}$ Tarek H. AbdelBary, MD ${ }^{1}$ \\ ${ }^{1}$ Department of Neurosurgery, Zagazig University, Zagazig, Egypt \\ Address for correspondence Mahmoud M. Taha, MD, PhD, \\ Surg J 2018;4:e164-e166. \\ Department of Neurosurgery, Faculty of Medicine, Zagazig University, \\ Zagazig, 44512, Egypt (e-mail: mahmoudlotfy1972@yahoo.co.uk).
}

\author{
Abstract \\ Keywords \\ - olfactory nerve \\ Schwannoma \\ - anterior cranial fossa \\ schwannoma \\ - olfactory groove \\ schwannoma \\ - olfactory \\ - schwannoma
}

Schwannomas are benign tumors, which arise from the Schwann cells of the central or peripheral nerves. They form $8 \%$ of all intracranial tumors and most of the cases arise from vestibular division of the $8^{\text {th }}$ cranial nerve. Rare cases are shown to arise from the olfactory or optic nerve, being devoid of myelin sheath. Up to date and according to our best of knowledge, 66 cases have been reported till now. Here we present a review of the literature and a case report of a 56-year-old male with an accidently discovered anterior cranial fossa schwannoma, following a road traffic accident. Tumor was completely excised, using a right frontal approach. Histopathology revealed AntoniA cellular pattern. Although rare, but olfactory nerve schwannomas should be included in the differential diagnosis in anterior cranial fossa space occupying lesions, and the approach should be designed taking into consideration, this rare entity.
Schwannomas are usually benign tumors, which arise from Schwann cells of central or peripheral nerves. They constitute $8 \%$ of all intracranial tumors and arise most commonly from the vestibular division of the $8^{\text {th }}$ cranial nerve. Other less common origins are the $5^{\text {th }}, 7^{\text {th }}, 9$ th, and $10^{\text {th }}$ cranial nerves. The occurrence of schwannoma not originating from cranial nerves is extremely rare, up to date. Only 66 cases have been reported ${ }^{1}$ and most commonly they are located in the anterior cranial fossa. ${ }^{2-4}$ Olfactory and optic nerves have no Schwann cells, which makes it theoretically impossible for schwannomas to arise in these locations, and arises a dilemma concerning the true pathogenesis of this tumor. ${ }^{1}$ Here, we present a review of literature and a case of olfactory nerve schwannoma, which was accidently discovered, while evaluating a patient with head injury.

\section{Case Presentation}

A 56-year-old male patient was presented to the emergency department, one day following a road traffic accident. Full history was obtained and thorough neurological examination was done, the patients Glasgow coma score was 13/15, he had right otorrhea, ecchymosis of both eyes, the right pupil was dilated fixed, and the left one was regular and reactive to light. Patient had history of old orthopedic instrumentation, 30 years ago.

CT (computed tomography) scan was obtained, which revealed pneumocephalus, and an incidental finding of a right frontal intra-axial mass with aggressive perilesional edema. Patient received conservative management, including dehydrating measures, antibiotics, and prophylactic antiepileptic. Complete investigations showed fracture maxilla and mandible.

Two days after admission, patient regained consciousness and re-evaluation showed right sixth nerve palsy, right optic atrophy, and anosmia. We recommended magnetic resonance imaging (MRI) brain with contrast, but it was not possible due to the old fracture and instrumentation, so a CT scan with contrast was done, as shown in - Fig. 1, and revealed an intraaxial mass with perilesional edema, and a cystic component. Our differential diagnosis was a high-grade glioma, an abscess, or metastatic deposits. Metastatic workup including CT chest, pelvi-abdominal ultrasonography, and tumor markers including PSA, $\alpha$-feto protein were all negative.

Expecting the mass to be intra-axial a right frontal craniotomy with trans-cortical approach was decided. Intraoperatively, palpation of the brain surface revealed no underlying cystic lesion, neither did aspiration, using a brain needle came up with received

April 2, 2018

accepted after revision

August 9, 2018
Dol https://doi.org/

10.1055/s-0038-1669991. ISSN 2378-5128.
Copyright (c) 2018 by Thieme Medical

Publishers, Inc., 333 Seventh Avenue, New York, NY 10001, USA. Tel: +1(212) 584-4662.
License terms

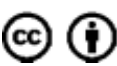




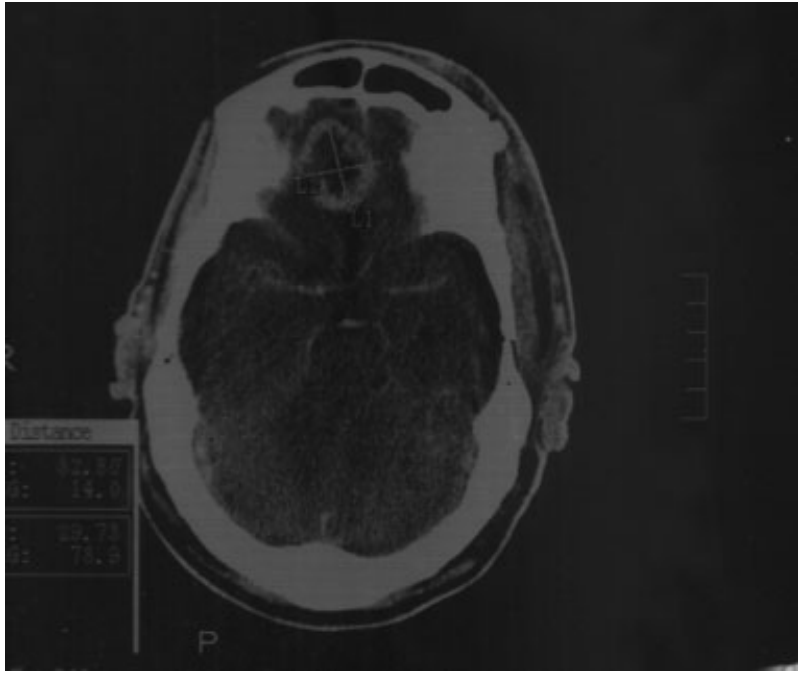

Fig. 1 Postcontrast computed tomography (CT) scan, showing an intra-axial right frontal space-occupying lesion.

any fluid. We proceeded with the transcortical approach, where a well-defined basal intraparenchymal mass appeared. The mass was reddish, soft in consistency, and was excised completely at the end of the procedure. Postoperative CT scan is shown in - Fig. 2. We were not able to identify neither optic nerves, nor the olfactory, at the end of our transcortical approach.

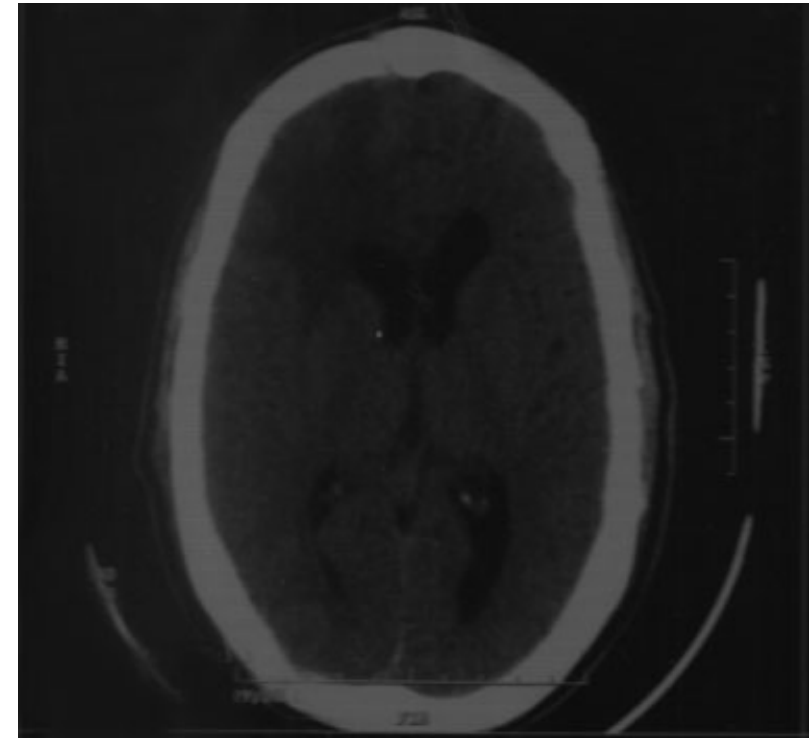

Fig. 3 Postoperative noncontrast computed tomography (CT) scan, showing complete excision of the tumor.

Histopathological examination showed benign spindleshaped cells, with elongated nuclei and fibrillary cytoplasm (Antoni-A pattern), and less cellular, loosely textured tumor areas, -Fig. 3.
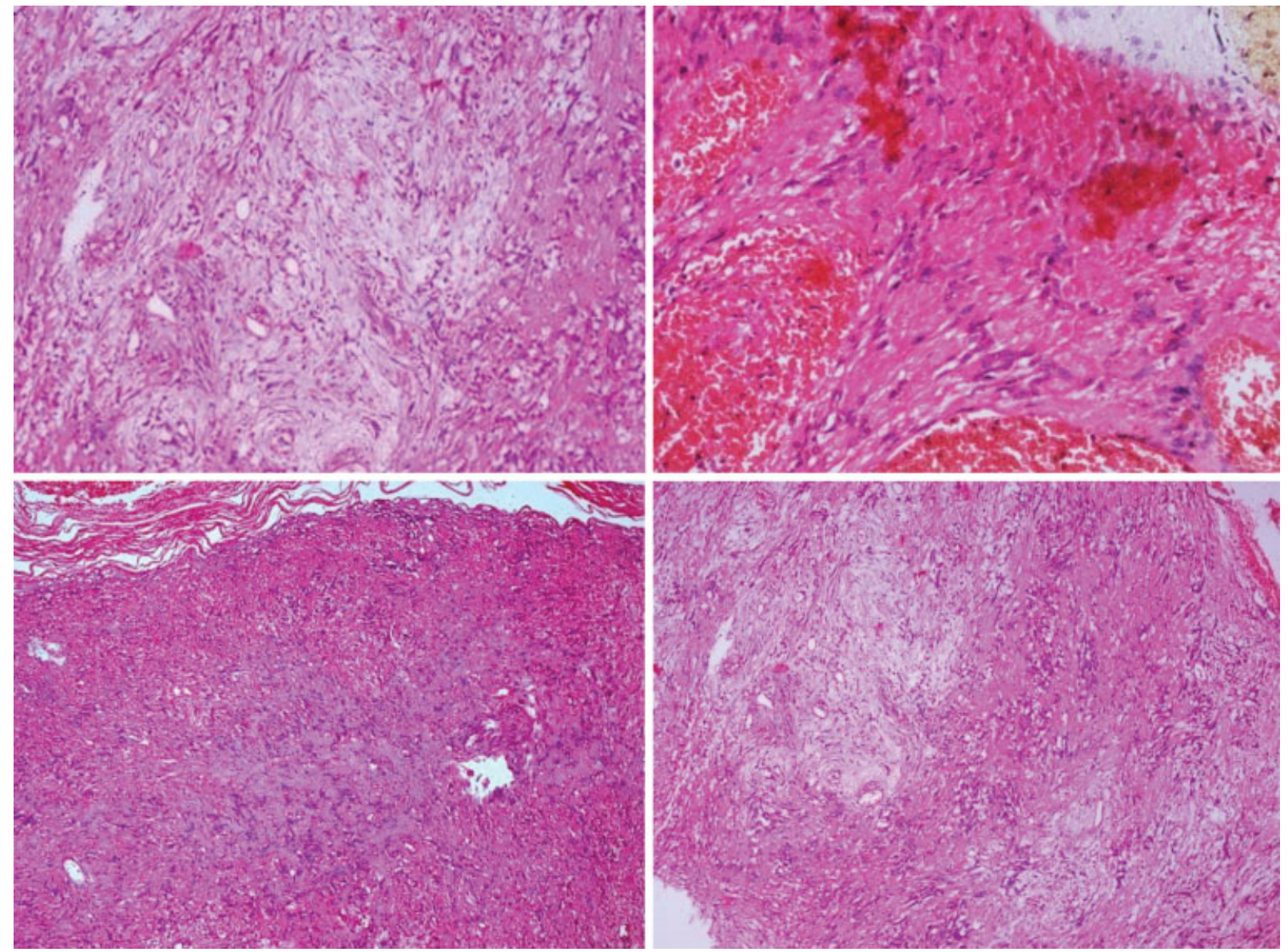

Fig. 2 Histopathological examination, showing Antoni type-A cellular pattern. 
Postoperatively, the patient was fully conscious, with improvement of his right sixth nerve palsy, but no improvement occurred in his smell, or right optic atrophy, right sixth nerve palsy, and anosmia.

\section{Discussion}

Schwannomas of the anterior cranial fossa are extremely rare, only 66 cases have been reported in literature to date. ${ }^{1}$ All reported cases were presented by headache, seizures, visual, or memory deficit. ${ }^{1,2}$ In our case, although examination of the patient showed right anosmia, optic atrophy, and right sixth nerve palsy, the patient had never complained or gave any previous history apart from mild diminution of vision in the right eye.

The origin of this entity is still debatable, since the fact that olfactory nerve lacks Schwann cells and has only oligodendrocytes. ${ }^{5}$ Existing theories suggest that these tumors arise from aberrant Schwann cells in the central nervous system (CNS), ${ }^{6}$ another theory suggests its transformation from mesenchymal pial cells or migration of neural crest cells present inside the $\mathrm{CNS},{ }^{7}$ both these theories may explain the origin of intraparenchymal schwannomas. ${ }^{2}$ Some basic science publications came to findings that olfactory nerve has schwann cells, which arise from precursor cells, which are present in the olfactory epithelium, and this makes the fact about presence of schwann cells, or not in the olfactory nerve unsettled yet. ${ }^{8}$ Other theories have been raised in a trial to explain the extra-axial or anterior skull base schwannomas, some authors posted that it may arise from the fila olfactoria, the embryonic terminal nerve, the nerve plexus of dural vessels, or from the ensheathing cells of the olfactory nerve and bulb. $6,9,10$

Our approach to the tumor was through a right frontal transcortical craniotomy, although the tumor was completely excised and the patient came out with no neurological deficit, yet this was not the ideal approach to this lesion. The cause of this pitfall was absence of the MRI, which couldn't be done due to the previous orthopedic instrumentation and unfamiliarity with this rare entity of anterior fossa tumors. Most reported cases were done through a subfrontal approach, which offers the best surgical corridor to the tumor, ${ }^{5,11,12}$ while some which had or had not a nasal sinus extension were done through endoscopy or endoscopy aided. ${ }^{13-17}$ All these cases had MRI done and although the possibility of a schwannomas was not in the differential diagnosis, but the nature of the lesion being a basal one was taken into consideration.

We were not able to identify neither the optics nor the olfactory nerve, yet some of the other authors, who adopted a subfrontal approach couldn't identify the nerve also, but no conclusion could be made, whether it was due to the origin of the tumor or was involved in it or just a displacement. ${ }^{2}$

\section{Conclusion}

Despite being a rare type with 67 cases (including our case), reported worldwide up till now, anterior cranial fossa schwannoma should be included in the differential diagnosis of anterior cranial fossa lesions and further steps toward understanding the exact origin, pathology and pathogenesis of such tumor entities should be achieved.

Conflict of Interest

None.

\section{References}

1 Esquivel-Miranda M, De la O Ríos E, Vargas-Valenciano E, MorenoMedina E. [Anterior skull-base schwannoma]. Neurocirugia (Astur) 2017;28(06):298-305

2 Figueiredo EG, Soga Y, Amorim RL, Oliveira AM, Teixeira MJ. The puzzling olfactory groove schwannoma: a systematic review. Skull Base 2011;21(01):31-36

3 Manto A, Manzo G, De Gennaro A, Martino V, Buono V, Serino A. An enigmatic clinical entity: A new case of olfactory schwannoma. Neuroradiol J 2016;29(03):174-178

4 Figueroa-Angel V, Rodríguez-Aceves CA, Calderon-Miranda WG, Escobar-Hernandez N, Joaquim AF, Moscote-Salazar LR. Subfrontal schwannoma: case report and review of literature. World Neurosurg 2017;111:386-390

5 Quick J, Hattingen E, Delbridge C, Seifert V, Marquardt G. Schwannoma of the olfactory nerve. Report of two cases and review of the literature. Clin Neurol Neurosurg 2015;132:44-46

6 Adachi K, Yoshida K, Miwa T, Ikeda E, Kawase T. Olfactory schwannoma. Acta Neurochir (Wien) 2007;149(06):605-610, discussion 610-611

7 Micovic MV, Zivkovic BM, Zivanovic JD, Bascarevic VL, Bogosavljevic V, Rasulic LG. Ancient olfactory schwannoma-case report and literature review. Turk Neurosurg 2017;27(04):656-651

8 Chuah MI, Au C. Olfactory schwann cells are derived from precursor cells in the olfactory epithelium. J Neurosci Res 1991;29 (02):172-180

9 Ahmad FU, Gupta A, Sharma MC, Shukla G, Mehta VS. The enigmatic origin of subfrontal schwannomas: report of a case without hyposmia. Acta Neurochir (Wien) 2006;148(06):671-672, discussion 672

10 Huang PP, Zagzag D, Benjamin V. Intracranial schwannoma presenting as a subfrontal tumor: case report. Neurosurgery 1997;40 (01):194-197

11 Okamoto H, Mineta T, Wakamiya T, et al. Two cases of subfrontal schwannoma, including a rare case located between the endosteal and meningeal layers of the dura. Neurol Med Chir (Tokyo) 2014; 54(08):681-685

12 Daglioglu E, Okay O, Dalgic A, Albayrak AL, Ergungor F. Cystic olfactory schwannoma of the anterior cranial base. Br J Neurosurg 2008;22(05):697-699

13 Blake DM, Husain Q Kanumuri VV, Svider PF, Eloy JA, Liu JK. Endoscopic endonasal resection of sinonasal and anterior skull base schwannomas. J Clin Neurosci 2014;21(08):1419-1423

14 Fujii T, Otani N, Doi K, et al. [Surgical treatment of a giant olfactory groove schwannoma:a case report]. No Shinkei Geka 2017;45(10): 919-928

15 Kanaan HA, Gardner PA, Yeaney G, et al. Expanded endoscopic endonasal resection of an olfactory schwannoma. J Neurosurg Pediatr 2008;2(04):261-265

16 Liu JK, Eloy JA. Expanded endoscopic endonasal transcribriform approach for resection of anterior skull base olfactory schwannoma. Neurosurg Focus 2012;32(Suppl 1):E3

17 Pereira MC, Peris-Celda M, Qian J, Kenning TJ, Pinheiro-Neto CD. Unilateral endoscopic endonasal surgery for resection of an olfactory schwannoma of the anterior cranial base in a patient with hereditary hemorrhagic telangiectasia. World Neurosurg 2016;89:729.e15-729.e20 